\title{
The quality of life when a partner has substance use problems: a scoping review
}

Bente Birkeland $^{1 *}$ (D), Kim Foster ${ }^{2,3}$, Anne S. Selbekk ${ }^{4}$, Magnhild M. Høie ${ }^{5}$, Torleif Ruud ${ }^{6,7}$ and Bente Weimand ${ }^{7,8}$

\begin{abstract}
Objective: To examine the existing body of knowledge on quality of life (QoL) in partners of people with substance use problems (PP-SUPS) to provide a synthesized summary of the evidence and identify gaps in our knowledge on the QoL of PP-SUPS.

Methods: A systematic scoping review was performed. Publications indexed in EMBASE, Medline, PsycINFO, CINAHL, SocINDEX, and CENTRAL were searched for original, empirical, peer-reviewed, full-length research papers that examined QoL in PP-SUPs. Research papers identified through a manual search of key references and known references by co-authors were also included. A total of 3070 abstracts were screened, 41 full-text papers examined, and nine were found to meet the inclusion criteria. Eligibility was determined in two steps by four and two independent researchers, respectively. The main findings were explored by content analysis.
\end{abstract}

Results: Eight of the nine included studies had quantitative designs, one had a mixed methods design, and no qualitative studies were found. Three studies were conducted exclusively among PP-SUPs, whereas the others included various subgroups. A majority of participants were women, and no study was conducted exclusively among men. Nearly half of the studies reported on whether there were minor children in the PPSUPs' household. The studies used established and generic QoL instruments based on different conceptual and theoretical perspectives on QoL. A majority of the studies found lower QoL in PP-SUPs than in general population, with substance use by the person with a SUP having the most impact on QoL of all evaluated factors. Two studies reported that gender was associated with QoL, with poor QoL being associated with being a male partner and vice versa for female partners.

Conclusions: Further research is needed to examine QoL in PP-SUPs exclusively. A variety of QoL instruments covering various, but limited, dimensions of the concept have been used in previous studies of PP-SUPS. Thus, obtaining a comprehensive understanding of PP-SUPs' QoL is challenging. Both qualitative and largescale quantitative designs should be used in research on QoL in PP-SUPs, particularly among those with a parenting role.

Keywords: Quality of life, Partners, Substance use

\section{Background}

Substance use problems (SUPs) affect the health and well-being of not only the person with the problem, but also their partners and families [1-3]. Substance use problems relate to consequences of substance use, such as physical and/or mental injuries, social and/or interpersonal problems, neglected major roles, and/or legal problems [4], and include a range of substances such as

\footnotetext{
* Correspondence: bente.b@sshf.no

${ }^{1}$ Addiction Department, Research Unit, Sørlandet Hospital HF, P.B. 416, 4604

Kristiansand, Norway
}

Full list of author information is available at the end of the article alcohol, opioids, cannabis, amphetamine/meth-amphetamine, and addictive drugs/medicines [5, 6]. Being the partner of a person with SUP involves being influenced by the consequences mentioned above. This study focuses on partners' perspective on the SUP of the person with the problem, and hence the term substance use problem (SUP) is chosen over the diagnostic term 'substance use disorder' [6]. From the partners' perspective there might exist a SUP when the use of substances disrupts the person's tasks and functions that are to be taken care of in the family and / or interferes with the

(c) The Author(s). 2018 Open Access This article is distributed under the terms of the Creative Commons Attribution 4.0 International License (http://creativecommons.org/licenses/by/4.0/), which permits unrestricted use, distribution, and reproduction in any medium, provided you give appropriate credit to the original author(s) and the source, provide a link to the Creative Commons license, and indicate if changes were made. The Creative Commons Public Domain Dedication waiver (http://creativecommons.org/publicdomain/zero/1.0/) applies to the data made available in this article, unless otherwise stated. 
relationships between people [7]. Partners might experience the person with a SUP as having physical,- emotional,- and/or relational problems; problems at work or school; with the police because of the use of substances; or spending a lot of time using substances, or recovering from a hangover [8]. In Norway, Ireland and Australia, an estimated $10-30 \%$ of relatives, including partners, are affected by SUP in a close family member based on prevalence studies $[5,9,10]$. These problems may negatively affect various areas of relatives' lives, such as poorer mental or somatic health $[1,8]$, social isolation, and poorer family conditions $[11,12]$. Studies have also shown reduced lifespan (years of life) in close relatives of people with SUPs $[1,13]$. In addition, studies report poorer socio-demographic conditions in close relatives: poverty, drop-out from school or work [1, 13, 14], and lower education levels have been reported in partners of persons with SUPs (PP-SUPs) compared to the general population [8].

The life areas reported above are essential dimensions of quality of life (QoL) in individuals, groups, and populations. Examining QoL can provide a broader perspective on individuals' total situation than a more narrow focus on, for example, health or financial outcomes [15]. Understanding and assessing QoL in different populations may serve as a basis for the development of knowledgebased measures to promote health and prevent possible negative outcomes in different areas of QoL in vulnerable populations, such as PP-SUPs. Studies investigating QoL have increased in recent years. The concept, however, has been defined in various ways and not always clarified or defined when used in research; therefore, QoL measures can differ across contexts. Barcaccia et al. [16] analyzed the concept of QoL in their review and concluded that psychological, spiritual, and social dimensions should be included in addition to dimensions strictly related to physical health when evaluating QoL. These dimensions, understood as inherent in the QoL concept, are in line with previous definitions: physical, psychological, social, and relational dimensions [17], as well as environmental and existential dimensions [18, 19]. Environmental dimensions may be understood in line with Moons et al. [20], who described living condition domains, such as economy, housing, and security. Together, all these dimensions (i.e., physical, psychological, social, relational, spiritual/existential, and environmental) may constitute a more comprehensive understanding of the concept of QoL and is the perspective on QoL that informs this review.

There has been an increase in the number of studies examining QoL in which a key aspect is a subjective, self-reported assessment of QoL [16]. Many measurements have been developed to measure QoL. As each measure focuses on different dimensions [21], QoL measures are not homogenous. The health-related QoL measure Short Form 36 (SF-36) [22] measures physical and mental health and considered a generic measure across illness states [23]. Though the SF-36 measures the individual's internal capability of life, other measures, such as the WHOQOL-BREF [18], measure inner life satisfaction or subjective enjoyment of life [24]. This indicates that health-related QoL measures tend to be more objective than subjective (as they ask questions such as whether the person has difficulty with mobility) than other measures such as rating of psychological well-being.

Relatives of persons with SUPs, including partners, have been recognized as an underserved population in healthcare [25], and QoL assessments can be useful in identifying those who struggle the most and need support or follow-up [15]. Examining the QoL of PP-SUPs will provide knowledge of their overall situation. Reviewing which QoL dimensions have been covered in studies of PP-SUPs' quality of life will provide evidence on knowledge gaps that require further investigation. Synthesized knowledge on QoL in partners may serve as the basis for preventing negative outcomes, such as burdens and health risk, both for the partners and other relatives or family members (i.e., children) [8], as well as interventions to improve their well-being and QoL. Mapping (i.e. summarizing the range of evidence to describe breadth and depth) of the research field [26] regarding QoL of PP-SUPs will contribute to a broader picture of their situation. To the best of our knowledge, synthesis and summary of this evidence has not been conducted previously. Therefore, the overall aim of this scoping review was to examine the extent, range, and nature of the body of knowledge on QoL in PP-SUPs for the purpose of providing a synthesized summary of the evidence and to identify gaps in our knowledge of the QoL of PP-SUPs. The research questions are: 1 . How has quality of life been investigated and measured with respect to PP-SUPs?, and, 2. How do PP-SUPs report their quality of life?

\section{Methods}

A scoping review was conducted in collaboration with two experienced librarians (J.H. and E.S.) using systematic search methods. Scoping reviews have been used increasingly in health services research during the past few years $[26,27]$, as they are a suitable method in areas in which little research exists, or when existing studies appear heterogeneous in their results and conclusions. Systematic scoping reviews require formal methods but differ from other reviews in some ways. First, a scoping review aims to examine the extent, range and nature of the body of literature of a specific topic in a broader perspective and does not necessarily assess the quality of the included studies. Second, scoping reviews are 
suitable for identifying research gaps and may also provide a mechanism for summarizing and disseminating research findings to policymakers and health care providers. Identifying gaps may also lead to more research in a particular field $[26,28]$. Due to a lack of a summary of knowledge on the QoL of PP-SUPs, such broad mapping is suitable for enabling an overview of the knowledge status in this area.

The choice of review method was also informed by initial searches in Google Scholar, followed by initial searches of the literature in two databases: EMBASE and PsycInfo. This search showed that studies investigating QoL in PP-SUPs were limited. To a large degree, studies were conducted among persons with SUPs, with a secondary aim to include their family members $[29,30]$. The results reflecting QoL in these studies were also different and ambiguous and did not necessarily specify the rationale for using the same QoL instruments across the included subgroups of participants (i.e., patients and family member, herein also partners) [29, 30].

In order to map the broader literature, there was an agreement to include articles with multi-dimensional perspectives on QoL. There was also an agreement to extract associations with QoL that were statistically significant (i.e. 95\% Confidence level.The approach for conducting systematic scoping reviews by Levac et al. [26] was used to guide the review based on the five-stage methodological framework developed by Arksey and O’Malley [28].

\section{Stage 1: Identifying the research question}

The central questions guiding this scoping review were:

1. How has quality of life been investigated and measured with respect to PP-SUPs?

2. How do PP-SUPs report their quality of life?

\section{Stage 2: Identifying relevant studies}

After the initial search in EMBASE and PsycInfo, six electronic databases were searched: EMBASE, Medline, PsycINFO, CINAHL, SocINDEX, and CENTRAL, with the last searches performed on June 23, 2017. No date limits were set. The search strategy included specifications of the context (substance use problems), participants (partners), and concept (quality of life) [31]. The search terms were then further identified. The context terms consisted of alcohol abuse, drug abuse, and drug dependence, with subgroups and different combinations. The participants terms consisted of partner, spouse, and significant other, also with subgroups and different combinations. The concept term consisted of quality of life, well-being, and life satisfaction.
Table 1 presents the search strategy that was used for EMBASE, which was adapted in minor ways for the other databases.

\section{Stage 3: Study selection Inclusion criteria}

Quantitative and qualitative peer-reviewed, original, full-length research papers were included. Research papers identified through a manual search of key references and references known by co-authors were also included. The overall aim included summarizing knowledge status; thus, study protocols and conference papers in which the results had not been published in peerreviewed journals were excluded. Because of limited time and resources, articles presented in languages other than English were also excluded. In addition, intervention studies and empirical papers which were not peerreviewed were excluded.

\section{Participants}

The participants were present partners to persons with SUPs. The population may have been examined exclusively in "pure" partner studies, or as a subsample in a total sample of close relatives.

\section{Concept}

The key concept that was reviewed was the self-reported quality of life, including multidimensional dimensions, where at least physical and psychological health domains and social/relational domains occur.. Studies that had a very narrow focus on well-being, e.g., psychological distress only, were excluded.

\section{Context}

The context of the participants in the various studies was being a present PP-SUP. The substance use was characterized or described as problematic, heavy, or severe, or in terms of a medical diagnosis, and as the main condition. The context may or may not include a treatment situation.

\section{Search strategy}

When performing the search strategy in the six different databases, a total of 4419 records were identified. These records were exported into EndNoteX8. Four records were identified through other sources, such as manually searching key references and feedback from co-authors. Duplicate records were then removed, resulting in 3070 records for screening the title and abstract. The screening was performed by two authors (BW and $\mathrm{BB}$ ), who independently compared the titles and abstracts of each record with the inclusion criteria. BW and $\mathrm{BB}$ finally agreed to include 41 records as relevant studies for full-text screening. The records considered eligible for 
Table 1 Search strategy

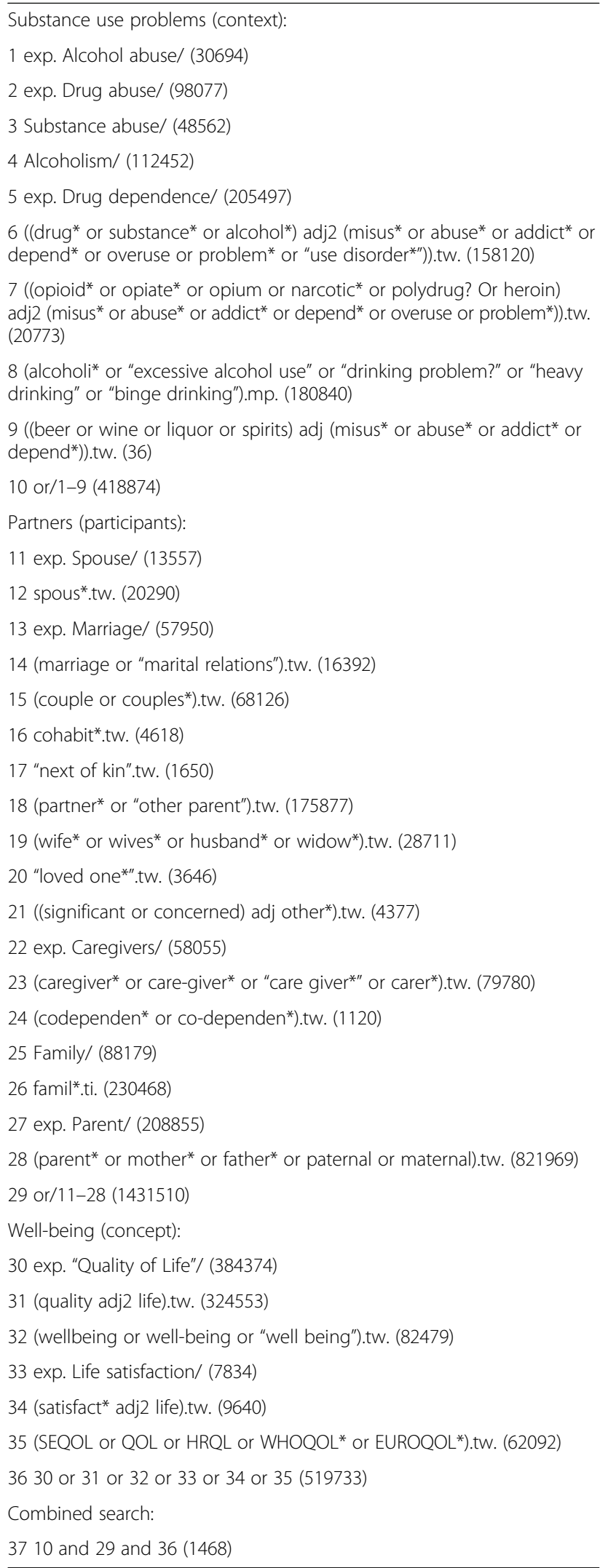

full-text screening were then distributed among two other authors, $\mathrm{AS}$ and $\mathrm{MH}$, in addition to $\mathrm{BB}$ and $\mathrm{BW}$, who independently screened the full-text studies to assess eligibility for inclusion in the review. One author (BB) screened the reference lists of the included studies. Of the 41 articles considered for inclusion, there was agreement on $36(88 \%)$. In cases in which there was disagreement or doubt (12\%), discussion meetings were held until an agreement was reached. In some cases, one of the other authors was consulted. Of the 41 screened full-text articles, 32 were excluded with reasons. The majority of these articles were excluded because the participants did not represent the relevant group (i.e. the persons with SUP had other main illnesses or conditions), they did not specifically present the results for the PP-SUP, the focus on well-being did not match our criteria for QoL, or well-being was measured in a very narrow way with, for example, only one QoL domain included. (e.g. stress, or well-being measured by using a depression scale only). This was also the case for the excluded qualitative articles, which in most cases focused on coping strategies as a measure of well-being. These articles were considered to diverge too much from the QoL domains. A total of nine articles were finally included in the review (Fig. 1).

\section{Stage 4: Charting the data}

Quality of life issues related to PP-SUPs were analyzed by three authors (BB, BW, and $\mathrm{KF}$ ) using steps from qualitative content analysis [32], including three main phases: preparation, organizing, and reporting. For this task, a structured data tool was used. One author (BB) extracted additional study characteristics, which were also reviewed by BW and then included in agreement between $\mathrm{BB}$ and $\mathrm{BW}$. As this was a scoping review, study quality (e.g., risks of bias, study strength) was not considered [28]. The tables show the systematization and categorization of relevant topics from the results of the studies included in this review, reflecting the review questions.

Stage 5: Collating, summarizing, and reporting the results The main characteristics of the nine included studies are presented in Table 2. The studies were grouped by year of publication. Studies published in the same year were grouped in alphabetical order of first authors' surnames.

\section{Findings}

The findings of the review are presented according to the review questions. Table 2 reports the general information and major findings of the reviewed publications. 


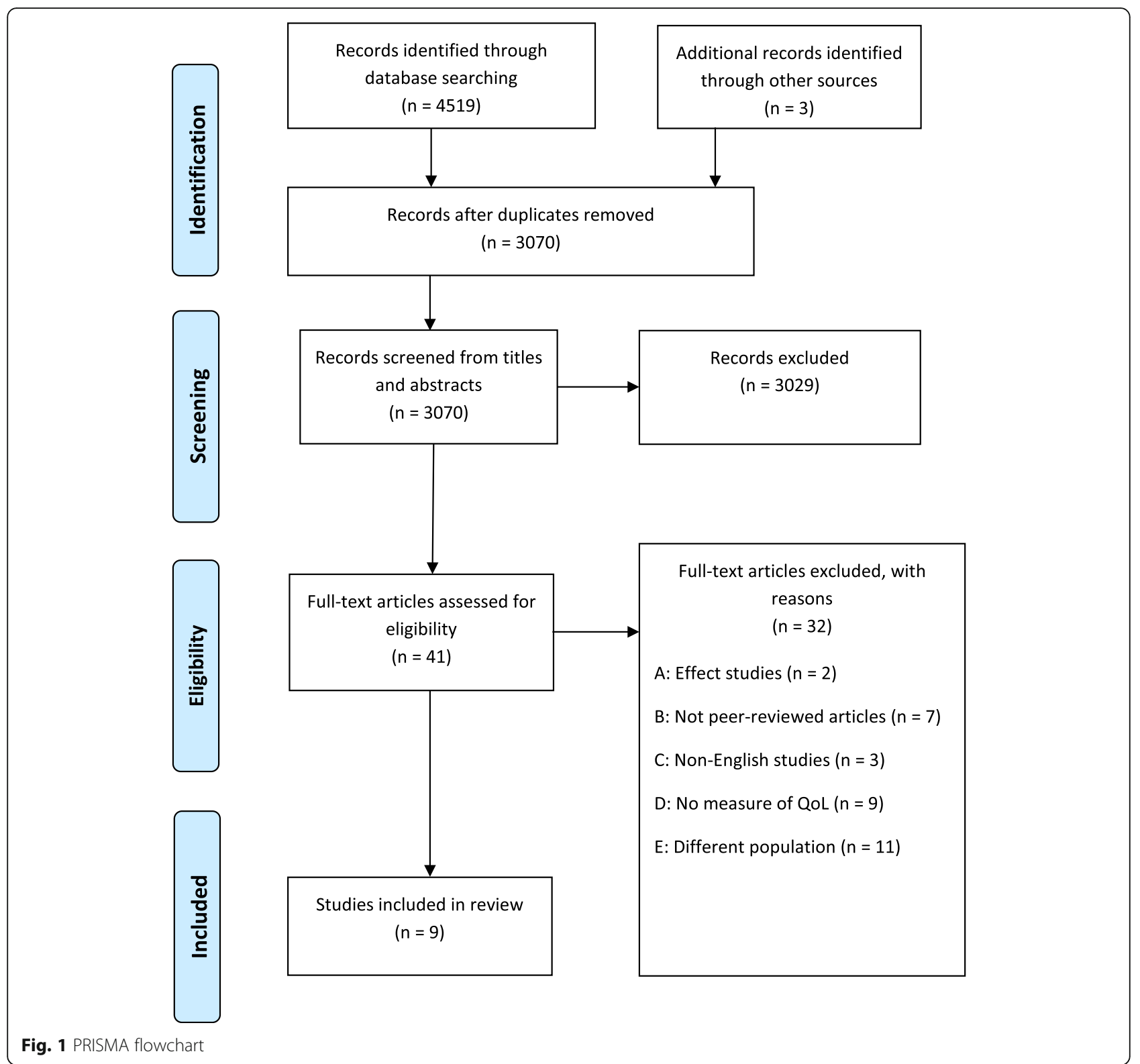

\section{How quality of life of PP-SUPs has been investigated and} measured

Three of the nine included studies were conducted in Australia [33-35]. The remaining studies originated from Canada [36], New Zealand [37], the Netherlands [30], USA [8], Croatia [29], and Spain [38]. The studies were spread over a wide timeframe, with two studies published before 2000 [35, 36] and seven published after 2010. The majority of the studies aimed to examine the impact of SUPs on close family members, with QoL as one of the primary outcomes. In four of the studies, the participants were recruited when their partner was in treatment $[29,30,36,38]$, in one study the participants were recruited through newspaper advertisements [35], and in one study the participants were recruited in mutual aid support groups (Al-Anon Family Groups and $\mathrm{FDH}$, a program of the Self-Help Addiction Resource Centre (SHARC), both in Australia) [34].

\section{Methods}

Eight of the studies had a quantitative design. Three studies were larger, general population surveys [8, 33, 37]. One was a case-control study [29], and four had a cross-sectional design [30, 35, 36, 38]). One of the studies had a mixed methods design in which QoL was included in the qualitative part [34]. No purely qualitative studies were found that met the inclusion criteria. 
Table 2 Studies examining QoL in partners to persons with substance use problems

\begin{tabular}{|c|c|c|c|c|c|c|}
\hline $\begin{array}{l}\text { Reference, } \\
\text { year, and } \\
\text { country }\end{array}$ & Aim and methods & $\begin{array}{l}\text { Sample size and } \\
\text { population }\end{array}$ & $\begin{array}{l}\text { Type of substance } \\
\text { use in the person } \\
\text { with SUP }\end{array}$ & $\begin{array}{l}\text { Test method } \\
\text { for associations } \\
\text { between having } \\
\text { a partner with } \\
\text { SUP and own QoL }\end{array}$ & $\begin{array}{l}\text { Controlled } \\
\text { for own SUP in } \\
\text { PP-SUP in } \\
\text { estimations } \\
\text { of associations } \\
\text { with QoL }\end{array}$ & $\begin{array}{l}\text { QoL perspectives } \\
\text { from results } \\
\text { section }\end{array}$ \\
\hline
\end{tabular}

\begin{tabular}{|c|c|}
\hline $\begin{array}{l}\text { 1. Brown } \\
\text { et al. [36] } \\
1995 \\
\text { Canada }\end{array}$ & $\begin{array}{l}\text { To explore gender } \\
\text { differences in marrie } \\
\text { substance abusers } \\
\text { admitted to treatmer } \\
\text { particularly with a vie } \\
\text { to clarifying the } \\
\text { relationship between } \\
\text { client functioning an } \\
\text { that of the spouse. } \\
\text { Cross-sectional study } \\
\text { QLQ (Quality of life } \\
\text { Questionnaire) }\end{array}$ \\
\hline $\begin{array}{l}\text { 2. Barber } \\
\text { et al. [35] } \\
1997 \\
\text { Australia }\end{array}$ & $\begin{array}{l}\text { To identify whether } \\
\text { some coping } \\
\text { responses are more } \\
\text { likely than others to } \\
\text { be associated with } \\
\text { psychological } \\
\text { adjustment in the } \\
\text { partners of drinkers } \\
\text { A multiple } \\
\text { regression study } \\
\text { Wolcott \& Glazer's } \\
12 \text {-item Well- } \\
\text { being scale }\end{array}$ \\
\hline
\end{tabular}

\section{$N=85$}

Gender of partners:

67 female and

18 male

Mean age of

partners: 37 years

Substance abuse Not performed
(alcohol and
other drug use)

other drug use)

Not controlled

Not controlled Gender differences for

$N=60$

Gender of partners:

57 women, 3 men

Mean age of

partners: 45 years

Heavy drinking

Standard multiple regression in partners' QoL, with men scoring significantly lower on:

- physical well-being

- parent-child relations

(less involvement with children and poorer parenting)

- altruistic behavior (inability to provide support to others)

Not controlled • No association for between the use of negative behaviors towards the drinker and psychological well-being, irrespective of being used when the partner is drunk or sober

- Negative behaviors towards the drinker when sober were marginally negatively related to psychological well-being

- Positive behaviors towards the drinker had a marginally significant correlation with well-being

\section{Dawson To examine the} et al. [8] association between

2007 partner alcohol problems and select physical and mental health outcomes among married or cohabiting women, before and after adjusting for potential confounders, and to compare these associations with those reflecting the impact of the women's own alcohol-use disorders

A cross-sectional, retrospective survey of a nationally representative sample of U.S. adults 18 years of age and older. Short Form-12 Health Survey Questionnaire,

\author{
11,683 married or \\ cohabiting women \\ (PP-SUPs) \\ Mean age of \\ partners: 42 years
Alcohol problems - Unadjusted (bivariate) regression models constructed to estimate the magnitude and significance of the associations between partner alcohol problems and the health outcomes.
- Linear regression models for associations between numbers of stressors and \\ QoL-scores.
}

Controlled for - Significantly lower psychological QoL scores in women whose partners had alcohol problems

- No significant difference in physical QoL between women with and without partner alcohol problems

- Lower psychological QoL was significantly associated with higher level of own alcohol use of the participants

- Partner alcohol problems were significantly associated with higher probability of being in fair or poor health and a lower mean 
Table 2 Studies examining QoL in partners to persons with substance use problems (Continued)

\begin{tabular}{|c|c|c|c|c|c|c|}
\hline $\begin{array}{l}\text { Reference, } \\
\text { year, and } \\
\text { country }\end{array}$ & Aim and methods & $\begin{array}{l}\text { Sample size and } \\
\text { population }\end{array}$ & $\begin{array}{l}\text { Type of substance } \\
\text { use in the person } \\
\text { with SUP }\end{array}$ & $\begin{array}{l}\text { Test method } \\
\text { for associations } \\
\text { between having } \\
\text { a partner with } \\
\text { SUP and own QoL }\end{array}$ & $\begin{array}{l}\text { Controlled } \\
\text { for own SUP in } \\
\text { PP-SUP in } \\
\text { estimations } \\
\text { of associations } \\
\text { with QoL }\end{array}$ & $\begin{array}{l}\text { QoL perspectives } \\
\text { from results } \\
\text { section }\end{array}$ \\
\hline
\end{tabular}

\begin{tabular}{|c|c|c|c|c|c|c|}
\hline & $\begin{array}{l}\text { Version } 2 \text { (SF-12v2)- } \\
\text { based physical quality } \\
\text { of life. SF-12v2-based } \\
\text { mental/ psychological } \\
\text { quality of life }\end{array}$ & & & & & $\begin{array}{l}\text { psychological } \\
\text { QoL scores }\end{array}$ \\
\hline $\begin{array}{l}\text { 4. Casswell } \\
\text { et al. [37] } \\
2011 \\
\text { New } \\
\text { Zealand }\end{array}$ & $\begin{array}{l}\text { A first step in investigating } \\
\text { relationships between } \\
\text { exposure to heavy drinkers } \\
\text { in respondents' lives with } \\
\text { measures of health status } \\
\text { and well-being } \\
\text { A cross-sectional general } \\
\text { population survey } \\
\text { European Quality of Life-5 } \\
\text { Dimensions (EQ-5D) } \\
\text { Personal Well-being } \\
\text { Index (PWI) }\end{array}$ & $\begin{array}{l}N=3068 \\
\text { (total sample) } \\
29 \% \text { had a heavy } \\
\text { drinker in their } \\
\text { lives } \\
\text { Partners to heavy } \\
\text { drinkers: } 15 \% \\
\text { Mean age of } \\
\text { partners: Not } \\
\text { reported } \\
\text { Gender of } \\
\text { partners: Not } \\
\text { reported (but for } \\
\text { total sample } 1232 \\
\text { males, } 1836 \text { females). }\end{array}$ & Heavy drinking & $\begin{array}{l}\text { Proportional } \\
\text { odds model } \\
\text { used to } \\
\text { predict } \\
\text { relationship }\end{array}$ & $\begin{array}{l}\text { Controlled for, } \\
\text { but not } \\
\text { reported on } \\
\text { PP-SUPs } \\
\text { exclusively }\end{array}$ & $\begin{array}{l}\text { - Three-quarters of } \\
\text { respondents who } \\
\text { had a heavy drinking } \\
\text { partner were in the } \\
\text { highest exposure } \\
\text { group (i.e., they were } \\
\text { exposed to three or } \\
\text { more heavy drinkers) } \\
\text { - QoL in PP-SUP not } \\
\text { reported } \\
\text { - Women reported } \\
\text { higher QoL } \\
\text { than men } \\
\text { - Poor QoL in } \\
\text { respondents } \\
\text { associated } \\
\text { significantly with } \\
\text { level of exposure to } \\
\text { heavy drinker } \\
\text { - The QoL domains } \\
\text { activity, pain, and } \\
\text { discomfort were } \\
\text { significantly } \\
\text { associated with high } \\
\text { level of exposure to } \\
\text { heavy drinkers } \\
\text { - Older age, low } \\
\text { income, low } \\
\text { education level, } \\
\text { higher levels of own } \\
\text { drinking were } \\
\text { significantly } \\
\text { associated with } \\
\text { lower QoL }\end{array}$ \\
\hline $\begin{array}{l}\text { 5. Hussaarts } \\
\text { et al. [30] } \\
2012 \\
\text { Netherlands }\end{array}$ & $\begin{array}{l}\text { Examine problem areas } \\
\text { that patients with } \\
\text { substance use } \\
\text { disorders and their } \\
\text { family members } \\
\text { experience in terms } \\
\text { of quality of relations, } \\
\text { psychological problems, } \\
\text { physical distress, and } \\
\text { quality of life. } \\
\text { Cross-sectional study } \\
\text { European Quality of } \\
\text { Life-5 Dimensions } \\
\text { (EQ-5D) }\end{array}$ & $\begin{array}{l}n=32 \\
\text { Dyads (persons } \\
\text { with substance } \\
\text { use disorders s } \\
\text { and a family } \\
\text { member)) were } \\
\text { recruited from a } \\
\text { substance abuse } \\
\text { treatment program } \\
22 \text { partners } \\
\text { Gender of partners: } \\
23 \% \text { males } \\
\text { Mean age of } \\
\text { partners: } 45 \text { years }\end{array}$ & $\begin{array}{l}\text { Substance use } \\
\text { disorder }\end{array}$ & Not performed & $\begin{array}{l}\text { Not controlled } \\
\text { for }\end{array}$ & $\begin{array}{l}\text { - No QoL differences } \\
\text { between subgroups } \\
\text { (patients, partners, } \\
\text { or parents) } \\
\text { - Poor QoL in family } \\
\text { members and in line } \\
\text { with heroin addicts }\end{array}$ \\
\hline $\begin{array}{l}\text { 6. Stenton } \\
\text { et al. [34] } \\
2014 \\
\text { Australia }\end{array}$ & $\begin{array}{l}\text { Examine challenges to } \\
\text { the health and well- } \\
\text { being of families of } \\
\text { people with alcohol } \\
\text { problems } \\
\text { A cross-sectional } \\
\text { survey incorporating } \\
\text { open-ended questions } \\
\text { for qualitative analysis }\end{array}$ & $\begin{array}{l}39 \text { Al-Anon members } \\
12 \text { partners } \\
\text { Gender of partners: } \\
\text { Not reported } \\
\text { Mean age of } \\
\text { partners: Not } \\
\text { reported }\end{array}$ & Problem drinking & $\begin{array}{l}\text { Pearson's } \\
\text { product } \\
\text { moment for } \\
\text { correlation }\end{array}$ & $\begin{array}{l}\text { Not controlled } \\
\text { for }\end{array}$ & $\begin{array}{l}\text { Quantitative part: } \\
\text { - Higher levels of } \\
\text { psychological } \\
\text { distress in } \\
\text { participants was } \\
\text { associated with } \\
\text { significantly poorer } \\
\text { overall QoL } \\
\text { - The participants' }\end{array}$ \\
\hline
\end{tabular}


Table 2 Studies examining QoL in partners to persons with substance use problems (Continued)

\begin{tabular}{|c|c|c|c|c|c|c|}
\hline $\begin{array}{l}\text { Reference, } \\
\text { year, and } \\
\text { country }\end{array}$ & Aim and methods & $\begin{array}{l}\text { Sample size and } \\
\text { population }\end{array}$ & $\begin{array}{l}\text { Type of substance } \\
\text { use in the person } \\
\text { with SUP }\end{array}$ & $\begin{array}{l}\text { Test method } \\
\text { for associations } \\
\text { between having } \\
\text { a partner with } \\
\text { SUP and own QoL }\end{array}$ & $\begin{array}{l}\text { Controlled } \\
\text { for own SUP in } \\
\text { PP-SUP in } \\
\text { estimations } \\
\text { of associations } \\
\text { with QoL }\end{array}$ & $\begin{array}{l}\text { QoL perspectives } \\
\text { from results } \\
\text { section }\end{array}$ \\
\hline
\end{tabular}

and closed-ended
questions for
quantitative analysis
Quantitative part:
Quality of life: single
question, "How would
you rate your quality of life?"
Qualitative part:
Open-ended questions
about the seriousness
of impact of their close
relative's drinking or
substance misuse on
their health and
well-being

7. Cicek et Comparing the quality al. [29] of life (QoL) and family

2015

Croatia

\section{Jiang et \\ al. [33]}

2015

Australia

burden in relatives of patients with heroin controls.

A prospective casecontrol study Brief (WHOQOL-BREF)

To identify which factors correlate with whether the respondent takes on this caring role dependence to healthy

World Health Organization Quality of Life Assessmentfor the person in their life whose drinking has most adversely affected them in the current year and to examine how caring for that person impacts the respondent's quality of life and wellbeing, and use of services Cross-sectional survey European Quality of Life-5 Dimensions (EQ-5D)

Personal Well-being Index (PWI)
A total of 50 heroindependent patients and 50 of their relatives, and 50 healthy subjects and 50 of their relatives were included in the study

Partners: 16\%

Gender of partners: Not reported, but $50 \%$ of total sample relatives were women

Mean age of partners: Not reported (but 41 years for total sample of relatives)

778 respondents (total survey sample 2649) reported they were harmed because of the drinking of someone they knew (most harmful

drinker; MHD).

67 partners

Gender of partners:

Not reported, but

$67 \%$ of respondents

harmed by MHD

were women

Mean age of partners:

Not reported

\section{Opioid}

dependence

Harmful drinking Not performed product- moment correlation and Spearman's rank correlation

satisfaction with a support group was associated with better overall QoL

- QoL in PP-SUP not reported

Qualitative part:

- Poor relationships and lack of trust

- Fear of aggression

- Anxiety, sadness, and grief

- Financial difficulties/ poverty

- Poor communication

Not controlled • No specific partner reports on QoL

- QoL significant lower in family members of patients with heroin dependence than controls

- All QoL subscale scores negatively correlated with the duration of illness
Not controlled • No QoL differences for
(EQ-5D) between

subgroups (partners and others)

- No significant differences in QoL (EQ-5D) in respondents who care for their 'most harmful drinker' (MHD) and those who did not

- No significant differences in QoL between specific categories of MHD relationships

- Personal well-being (PWI) significantly worse for people harmed by MHD than people who had no MHD in life

- Poorer personal well-being (PWI) for caregivers of MHD in the household than non-caregivers 
Table 2 Studies examining QoL in partners to persons with substance use problems (Continued)

\begin{tabular}{|c|c|c|c|c|c|c|}
\hline $\begin{array}{l}\text { Reference, } \\
\text { year, and } \\
\text { country }\end{array}$ & Aim and methods & $\begin{array}{l}\text { Sample size and } \\
\text { population }\end{array}$ & $\begin{array}{l}\text { Type of substance } \\
\text { use in the person } \\
\text { with SUP }\end{array}$ & $\begin{array}{l}\text { Test method } \\
\text { for associations } \\
\text { between having } \\
\text { a partner with } \\
\text { SUP and own QoL }\end{array}$ & $\begin{array}{l}\text { Controlled } \\
\text { for own SUP in } \\
\text { PP-SUP in } \\
\text { estimations } \\
\text { of associations } \\
\text { with QoL }\end{array}$ & $\begin{array}{l}\text { QoL perspectives } \\
\text { from results } \\
\text { section }\end{array}$ \\
\hline $\begin{array}{l}\text { 9. Nogueira } \\
\text { et al. [38] } \\
2015 \\
\text { Spain }\end{array}$ & $\begin{array}{l}\text { To provide new } \\
\text { empirical evidence } \\
\text { about the effects of } \\
\text { alcohol dependence } \\
\text { on the health-related } \\
\text { QoL of the dependent } \\
\text { person and those } \\
\text { around them using } \\
\text { the general population } \\
\text { as the control group } \\
\text { Cross-sectional study } \\
\text { Short-Form Health } \\
\text { Survey-36 (SF-6D) }\end{array}$ & $\begin{array}{l}150 \text { patients with } \\
\text { alcohol dependence, } \\
64 \text { family members } \\
\text { of patients with } \\
\text { alcohol dependence, } \\
\text { and } 600 \text { persons from } \\
\text { the general population } \\
67.7 \% \text { partners } \\
\text { Gender of partners: } \\
\text { Not reported } \\
\text { Mean age of partners: } \\
\text { Not reported }\end{array}$ & $\begin{array}{l}\text { Alcohol } \\
\text { dependence }\end{array}$ & $\begin{array}{l}\text { Logistic } \\
\text { regressions }\end{array}$ & $\begin{array}{l}\text { Not controlled } \\
\text { for }\end{array}$ & $\begin{array}{l}\text { QoL not reported for } \\
\text { partners } \\
\text { - Significantly lower } \\
\text { QoL in family } \\
\text { members than in } \\
\text { general population } \\
\text { (no specific partner } \\
\text { reports on QoL) } \\
\text { - Reduction in mean } \\
\text { utility scores in SF- } \\
6 \text { D dimensions in } \\
\text { family members, } \\
\text { particularly in mental } \\
\text { health and vitality, } \\
\text { with a positive } \\
\text { impact from physical } \\
\text { function compared } \\
\text { to the general } \\
\text { population } \\
\text { - Age and gender } \\
\text { (being a woman) } \\
\text { negatively correlated } \\
\text { with QoL }\end{array}$ \\
\hline
\end{tabular}

\section{QoL measures}

The instruments used, QoL domains, and studies are listed in Table 3. A wide range of instruments were used. Five of the studies used instruments covering health-related QoL. Two of these five studies used two different versions of the SF-36: the SF-12 [8] and SF-6D [38]. The SF versions; $-36 /-12 /-6 \mathrm{D}$ are described both as generic health measures and health related quality of life measures. These instruments cover eight and six domains on mental and physical health, respectively [39-42]. As for the three studies using EQ-5D [30, 33, 37], a QoL measure covering five dimensions of health [43], two of them $[33,37]$ supplied the Personal Well-being Index PWI $[44,45]$ to capture measures of life and life satisfaction as a whole. Another study [36] used both the PWI and the Quality of Life Questionnaire (QLQ), which includes eight scales on well-being [46].

The rest of the quantitative studies $(n=3)$ measured QoL using different instruments covering a range of QoL with at least health, social, and relational domains. One study [29] used a Turkish version of the WHOQOL-BREF, which includes eight domains on physical and psychological health and social relations [47]. Some of the instruments covered existential, environmental, and living standard domains. Barber and Gilbertson [35] used Wolcott \& Glazer's 12-item well-being scale [48] covering standard of living domains, relational domains, and feelings of self, and including some questions on health. Finally, the study using a single question asking the participants to rate their perceived overall QoL [34] did not report which domains this was meant to cover. They did, however, include a qualitative part with questions about health and well-being, which was supposed to cover QoL.

\section{Population}

Only three of the nine included studies $[8,35,36]$ were conducted among PP-SUPs exclusively. The six remaining studies [29, 30, 33, 34, 37, 38] were conducted among other close relatives to persons with SUPs, including a percentage of PP-SUPs.

Only four of the nine selected studies provided socio-demographic details of the PP-SUPs regarding age and gender, and three of these five studies also reported on minor children living in the household. In the three studies evaluating PP-SUPs exclusively, the mean age was 42 years [8], 45 years [35], and 37 years [36]. Hussaarts et al. [30] reported a mean age of 45 years in PP-SUPs in the total sample of relatives. The same studies reported the gender of PP-SUPs. There was a large proportion of female partners (average $88 \%$ ). One study had $77 \%$ female partners [30]; in the rest of the studies, the proportion of women ranged from 79\% [36] to $95 \%$ [35]. Finally, one study [8] was conducted among females only. No studies conducted exclusively among men were found. Five of the remaining studies did not report on socio-demographic variables, such as age and gender, in PP-SUPs specifically [29, 33, 34, 37, 38]. In 
Table 3 QoL measures and domains

\begin{tabular}{|c|c|c|}
\hline Instrument & QoL domains & Study \\
\hline SF-12 (12 items) [39] & $\begin{array}{l}\text { Physical functioning } \\
\text { Role physical } \\
\text { Bodily pain } \\
\text { General health } \\
\text { Mental health } \\
\text { Role emotional } \\
\text { Social functioning } \\
\text { Vitality }\end{array}$ & {$[8]$} \\
\hline SF-6D (6 items) [42] & $\begin{array}{l}\text { Physical functioning } \\
\text { Role limitations } \\
\text { Pain } \\
\text { Mental health } \\
\text { Social functioning } \\
\text { Vitality }\end{array}$ & [38] \\
\hline $\begin{array}{l}\text { EQ-5D ( } 5 \text { items and a } \\
\text { VAS on current overall } \\
\text { health) [43] }\end{array}$ & $\begin{array}{l}\text { Mobility } \\
\text { Self-care } \\
\text { Usual activities } \\
\text { Pain/discomfort } \\
\text { Anxiety/depression }\end{array}$ & {$[30,33,37]$} \\
\hline $\begin{array}{l}\text { Personal Well-being } \\
\text { Index (PWI) (8 items and } \\
\text { a single question of } \\
\text { satisfaction with life as } \\
\text { a whole) [45] }\end{array}$ & $\begin{array}{l}\text { Standard of living } \\
\text { Personal health } \\
\text { Achieving in life } \\
\text { Personal relationships } \\
\text { Personal safety } \\
\text { Community connectedness } \\
\text { Future security } \\
\text { Spirituality/religion }\end{array}$ & {$[33,37]$} \\
\hline $\begin{array}{l}\text { WHOQOL-BREF (27 } \\
\text { items) [18] }\end{array}$ & $\begin{array}{l}\text { Physical } \\
\text { Psychological } \\
\text { Social relationships } \\
\text { Environment }\end{array}$ & [29] \\
\hline $\begin{array}{l}\text { Quality of Life } \\
\text { Questionnaire (QLQ) } \\
\text { (192 items) [46] }\end{array}$ & $\begin{array}{l}\text { Material well-being } \\
\text { Physical well-being } \\
\text { Personal growth } \\
\text { Marital relations } \\
\text { Parent/child relations } \\
\text { Extended family relations } \\
\text { Extramarital relations } \\
\text { Altruistic behavior }\end{array}$ & {$[36]$} \\
\hline $\begin{array}{l}\text { Wolcott \& Glezer's } \\
\text { well-being scale ( } 12 \\
\text { items) [48] }\end{array}$ & $\begin{array}{l}\text { Standard of living } \\
\text { Relationship } \\
\text { Personal feelings of self-worth }\end{array}$ & {$[35]$} \\
\hline $\begin{array}{l}\text { A single question on } \\
\text { overall QoL: How } \\
\text { satisfied are you with } \\
\text { your life? }\end{array}$ & $\begin{array}{l}\text { Open-ended questions about } \\
\text { the seriousness of the impact } \\
\text { of their close relative's drinking } \\
\text { or substance misuse on their } \\
\text { health and well-being }\end{array}$ & [34] \\
\hline
\end{tabular}

addition, when reporting on demographic variables, three of the nine included studies reported that some of the PP-SUPs were parents to minor children living in the household, namely 58\% [36], 50\% [8], and 54\% [30].

\section{How PP-SUPs report their QoL}

Three of the nine studies reported QoL exclusively in PP-SUPs $[8,35,36]$, but varying QoL results were reported. Only one of the included studies controlled for own SUP in PP-SUPs in estimations of associations with QoL. In this study, a survey investigating the impact of partner alcohol problems in American women [8], lower
QoL was found in PP-SUPs than the general population. Lower psychological QoL was significantly associated with higher level of own alcohol use of the participants. The partners' alcohol use appeared however to have at least as great negative effect on QoL in PP-SUPs as the participants' own alcohol use. In another study exploring gender differences in spouses of partners in treatment [36], male partners reported lower QoL than female partners. In addition, the male partners' lower QoL was associated with poor relationships with their children and poor social support skills. The third study examining partners living with a heavy drinker [35] found no associations between PP-SUPs' psychological well-being and negative behavior towards the drinker, regardless of whether such behavior was present when the partner was drunk or sober. The authors underlined that wellbeing may also be determined by other factors.

The two studies reporting PP-SUPs as part of the overall study [30, 33] also reported on partners' QoL specifically. When examining differences between subgroups, they both found that the PP-SUPs' QoL did not differ significantly from the other subgroups of participants, such as SUP patients or other relatives [30, 33] . These studies also presented various results regarding QoL. Both studies [30, 33] found that the relatives [30, 33], including PP-SUPs, reported significantly lower QoL than the general population. The authors [30, 33] proposed that the poor QoL may have been due to the strains and burdens of living with or caring for a person with a SUP. Further, when examining factors associated with QoL, both studies [30, 33] found that poor QoL in relatives $[30,33]$ is associated with the severity of the substance use in the person with SUPs. Jiang et al. [33] also found that caring for the person with alcohol use is negatively associated with QoL.

The results of the last four studies [29, 34, 37, 38] did not differ between subgroups, but reported on relatives of people with SUP as a whole, though they reported a percentage of PP-SUPs in their results. All of these studies found poorer QoL in relatives of people with SUP than in the general population or controls, with various factors that may explain this difference. In a population survey examining the negative impact of exposure to others' drinking, Casswell et al. [37] found a reduction of QoL that was significantly related to an increase in the level of such exposure, and that $75 \%$ of the participants represented in the group reporting highest exposure were PP-SUPs. They also found a strong association between higher QoL and being a woman, though being unemployed/sick and on low income was associated with lower levels of QoL for all participants. In the estimations of associations with QoL in the participants, one of the studies found that higher levels of the relatives' (including PP-SUPs) own drinking were significantly 
associated with lower QoL [37]. The other study [34] found no significant associations between the relatives' (including PP-SUPs) own substance use and measures of QoL. In a study of 150 alcohol-dependent persons and 64 family members of alcoholics, Nogueira et al. [38] found that poor QoL in family members was generally associated with higher age and being a woman, whereas education and living with a partner positively correlated with QoL.

The remaining studies including relatives $[29,34]$ in general reported a negative correlation between low QoL in relatives and duration of heroin dependence, age, and education of both patients and relatives, and the onset age of heroin use. Stenton et al. [34] found that poor QoL in relatives was associated with psychological distress, whereas better QoL was associated with the level of satisfaction with attendance in a mutual aid support group. In this study they found no significant associations between relatives' (own) alcohol consumption and measures of QoL or well-being.

\section{Discussion}

The studies included in this scoping review originated from a wide range of countries, and the majority were conducted after 2010, which indicates an increased interest in research focusing on both QoL and PP-SUPs. One study with a mixed methods design [34] was included and no qualitative studies matched our inclusion criteria of exploring PP-SUP experiences with QoL were found in the research emerging after 2010. The majority of the studies used established and generic instruments when examining QoL. However, these instruments are based on different concepts and theoretical perspectives of QoL; therefore, findings cannot be consistently compared across studies. Many studies also utilised different comparison groups (e.g. the general population, people who had no person with SUP in their life, controls, patients vs. partners, vs. parents, etc.), which shows a heterogeneity between studies.

As for the instruments used to measure QoL, two of the studies that used the EQ-5D, a QoL instrument solely covering health domains, added the PWI with broader domains [33, 37]. Three other studies using EQ-5D [30], SF-12 [8], and SF-6 [38], did not include other instruments to add additional dimensions other than health when reporting on QoL. As health-related QoL measures often refer to an illness and treatment of patients [23], and tend to be more "objective" as they target specific functioning levels, they may have been considered suitable when examining health-related QoL in persons with SUPs. The question remains whether this reflects the QoL dimensions that are most important to family members or relatives in general or PP-SUPs specifically; these persons may experience a difficult life situation but are not necessarily ill. The remaining four quantitative studies [11, 29, 35, 36] used instruments covering a wider range of QoL domains in addition to health. This included at least social and/or relational domains, and some of them even existential or environmental domains. Conclusively, though all the instruments covered the health domain, only half of the studies made use of instruments that embrace QoL in a broader manner, including at least social and relational dimensions. Therefore, the findings are heterogeneous because researchers are not consistently using the same measures. Many studies only include particular dimensions of QoL rather than a more comprehensive concept of QoL. The mixed methods study [34], which included an overall question about quality of life, introduced a broader perspective on QoL by including a single qualitative question about the participant's well-being in different areas. This qualitative information can provide further contextual information and explanations for quantitative findings and may be useful to include in future research on QoL.

For future research of PP-SUPs, QoL measures that capture the broader dimensions of QoL are recommended. In addition, generic instruments that provide the possibility of cross-population comparisons would be useful. It also seems that multi-dimensional QoL forms could better capture variations in the life situation of these partners and provide a more holistic understanding of their overall life situation's impact on their QoL. Of the instruments included in the studies in this review, only WHOQOL-BREF include social, relational, and existential dimensions in addition to physical and mental health. To capture more dimensions than those covered by the highly health-specific instruments (e.g., EQ-5D, SF-6D, and SF-12), they can be used together with PWI, which also includes social, relational, and existential dimensions.

Only three of the included studies focused on PP-SUPs exclusively. However, two of the other studies including PP-SUPs as a subgroup did report on their QoL. The remaining studies did not differ between subgroups when presenting QoL results, but presented the QoL results to apply to the entire sample. Thus, more research is needed that focuses on PP-SUPs exclusively. In the case of socio-demographic variables, the average age of PP-SUPs is relatively low ( 42 years), which may reflect the fact that in three of the nine reviewed studies over half of the participants were described as caring for minor children. Parenting was however not themed specifically, which indicates a knowledge gap. Women comprised more than $3 /$ 4 of the participants on average. This is in line with other research conducted among PP-SUPs in which the proportion of women has often been higher [13, 14, 49]. Though the findings by Dawson et al. [8] represent female partners only, and the rest of the studies reported a majority of female PP-SUPs, no studies were found that focus 
exclusively on male PP-SUPs. Therefore, there is a gap in knowledge on the QoL of male partners, especially as male partners have reported very poor QoL [36], and further research on male partners' QoL is needed.

A key finding was that, in the majority of the studies, substance use by the person with SUPs was the factor that related most to poor QoL among the participants, including PP-SUPs $[8,30,33,35]$. An association was found between severity of SUPs and poorer QoL in PP-SUPs [30, $33,37]$. The majority of studies also reported that the participants, including PP-SUPs, described a lower QoL than the general population. These findings indicate that substance use itself has a great impact on the PP-SUPs' QoL. One study found that PP-SUPs' QoL was more affected by SUPs in a partner than the PP-SUPs' own substance use [8]. In addition, several of the studies showed that PPSUPs had equally poor QoL as people with SUPs. This indicates a very stressful life situation. Although they are not by definition ill, long-term and serious substance use problems have a major impact on PP-SUPs' QoL. Using a broad measure of QoL that includes at least health, social, and relational dimensions, rather than pure health-specific QoL measures, in future research could be more suitable for capturing partners' life situations.

The results describing associations with QoL varied greatly. In addition to the impact of SUPs on QoL, there are some specific findings that need to be discussed and addressed with respect to PP-SUPs. Firstly, only one of the studies controlled for PP-SUPs' own substance use in their estimations of associations between having a partner with SUP and lower QoL. This study found a significant association between lower QoL in PP-SUPs and own substance use. Two other studies, conducted among relatives such as people exposed to heavy drinkers [37] and family members of people with alcohol problems [34], respectively, also examined associations between the relatives' own substance use and QoL, but did not report on PP-SUPs exclusively. One of these studies [37] found that substance use in the participants was associated with QoL. Hence, we cannot know how the PP-SUP's own substance use, and their partners' substance use, respectively, impact on partners' QoL. It is interesting however to see that male PP-SUPs have lower QOL (than female PP-SUPs) in a study that does not control for own consumption [36], whereas female PP-SUPs have lower QOL (than the general population) in the study that does control for own consumption [8]. This indicates that own consumption may be an important confounder to control for. Controlling for own substance use may be particularly important for disentangling gender differences in associations between being a PP-SUP and QoL. This result represents a gap which needs to be further examined in future research. Secondly, the fact that three of the studies $[8,30,36]$ reported on whether the partners had minor children living in the household must be considered when presenting the associations with QoL. This is especially important when poor QoL was found to be associated with being male and poor parent/child relations [36]. Several studies have shown that the parent/ child relationship is disrupted due to SUPs in a parent [2, 12, 50]. The PP-SUPs' poor QoL may influence the capacity to fill the parenting role. Taken together, these findings underline the importance of paying attention to PP-SUPs that also have a parenting role. Possible negative outcomes for partners is relevant not only to tailor support for their own sake, but also to enhance parenting and prevent negative outcomes for the children. Conversely, better parenting ability may mutually reinforce the parent's overall situation [51].

As for PP-SUPs' positive associations with QoL, one study conducted in 1997 found that positive behavior towards their partner with SUPs was associated to some degree with PP-SUPs' QoL [35]. Though these are also important findings to address clinically, a minority of studies seem to have examined other factors associated with QoL in PP-SUPs, both positive and negative. Studies reporting on PP-SUPs' positive associations with QoL seem limited, and there is a gap in knowledge in this area. Studies investigating and exploring QoL qualitatively and quantitatively in PP-SUPs are also needed.

\section{Conclusions}

This scoping review shows that poor QoL of PP-SUPs is associated with the partner's SUP, and this should be addressed by health personnel who need to increase focus on PP-SUPs' QoL when patients with such problems are in treatment. This result is also relevant for policymakers. PP-SUPs should be included in the development of national guidelines based on larger scale research. The importance of national guidelines being evidence-based is emphasized; therefore, such evidence must be valid and reliable. Currently, the evidence is ambiguous, and there is a need for larger generalizable studies. Furthermore, there is a need for more research among PP-SUPs who also are parents to minor children as poor QoL may affect parenting. Gender issues should also be taken into consideration when conducting such studies.

This review has revealed some important gaps with respect to knowledge about QoL in PP-SUPs. First, due to the minority of studies conducted among PP-SUPs exclusively, there is a need for further research examining QoL in this group. QoL has been studied in PP-SUPs to a limited extent. In addition, a variety of QoL instruments with various dimensions of the concept included have been used in studies of this particular population. This indicates a challenge in making comparisons between groups. On the one hand, generic instruments that may compare this population with the general population or other 
at-risk-groups exist, whereas on the other hand, generic instruments may fail to capture specific areas of importance to certain populations, such as PP-SUPs. Thus, in addition to studies with larger scaled quantitative designs, a need exists for research exploring QoL qualitatively in this particular group, especially among PP-SUPs who also have a parenting role.

\section{Strengths and limitations}

The main strength of the present scoping review is the comprehensive database search without a date limit. The search was conducted with comprehensive search terms, which identified a large number of studies. This strength is largely due to close collaboration with two highly experienced academic librarians from different disciplines during the search. The titles and abstracts were screened thoroughly and systematically performed by two authors. Full-text studies were further screened by four authors, followed by reference lists and discussion meetings, which also assured against a loss of relevant studies. However, studies in languages other than English were not included, which may have caused some relevant records to be missed. Though the search was performed in six databases, this number is not exhaustive. However, the selected databases and the search performed were advised by experienced academic librarians in order to cast as wide a net as possible regarding the population, concept, and context.

\section{Acknowledgements}

The work on this scoping review was supported by Addiction Unit, Sorlandet Hospital, and the National Competence Network Children's Best Interest. We are also very grateful for the assistance of the highly experienced academic librarians Jørn Hjørungnes (Sorlandet Hospital) and Ellen Sejersted (University of Agder), who collaborated during the search process.

\section{Funding}

This study was funded by Addiction Unit, and BarnsBeste (Children's Best Interest) at Sørlandet Hospital Trust, with additional funding from the Norwegian Directorate of Health.

\section{Availability of data and materials}

Data sharing not applicable to this article as no datasets were generated or analysed.

\begin{abstract}
Authors' contributions
$\mathrm{BB}$ and $\mathrm{BW}$ designed the study and the literature search strategy, in corporation with librarians. BB undertook data cleaning, and BB and BW performed title and abstract screening. BB, BW, ASS and MMH undertook full paper assessment. BB, $\mathrm{KF}$, and $\mathrm{BW}$ performed the data extraction and analysis of all data, with input from ASS, MMH and TR as required. BB and BW drafted and revised the paper, followed by a critical revision from KF, TR, ASS and MMH. All authors gave final approval of the manuscript and are accountable for all aspects of the accuracy and integrity of the work.
\end{abstract}

Ethics approval and consent to participate

Ethical approval was not required for this study.

\section{Consent for publication}

The paper does not contain any personal data.
Competing interests

The authors declare that they have no competing interests.

\section{Publisher's Note}

Springer Nature remains neutral with regard to jurisdictional claims in published maps and institutional affiliations.

\section{Author details}

${ }^{1}$ Addiction Department, Research Unit, Sørlandet Hospital HF, P.B. 416, 4604 Kristiansand, Norway. ${ }^{2}$ School of Nursing, Midwifery \& Paramedicine, Australian Catholic University, Victoria, Australia. ${ }^{3}$ NorthWestern Mental Health, Victoria, Australia. ${ }^{4}$ Department for Research and Development, Rogaland A-senter, Stavanger, Norway. ${ }^{5}$ Department of Psychosocial Health, Faculthy of Health and Sports Science, University of Agder, Grimstad, Norway. ${ }^{6}$ Institute of Clinical Medicine, University of Oslo, Oslo, Norway. ${ }^{7}$ Division Mental Health Services, R\&D Department, Akershus University Hospital, 1478, Lørenskog, Norway. ${ }^{8}$ Faculty of Health Sciences, Oslo Metropolitan University, Oslo, Norway.

Received: 1 June 2018 Accepted: 1 November 2018

Published online: 20 November 2018

\section{References}

1. Hjärn A, Arat A, Vinnerljung B. Growing up with parental substance abuse or mental illness - how is life as adults? [att växa upp med förelder som har missbruksproblem eller psykisk sjukdom - hur ser livet ut i vuxen ålder?]. Stockholm: Stockholms Universitet/Karolinska Institutet i samarbete med Institutionen för socialt arbete vid Stockholms universitet; 2014.

2. Templeton L, Zohadi S, Galvani S, Velleman R. Looking beyond risk: Parental substance misuse: Scoping study. Scotland: Scottish Government; 2006.

3. Orford J, Natera G, Davies J, Nava A, Mora J, Rigby K, et al. Stresses and strains for family members living with drinking or drug problems in England and Mexico. Salud Mental. 1998;21(1):13.

4. Hasin DS, O'Brien CP, Auriacombe M, Borges G, Bucholz K, Budney A, et al. Dsm-5 criteria for substance use disorders: recommendations and rationale. Am J Psychiatry. 2013;170(8):834-51.

5. National Institute of Public Health Norway. Public Health report 2014:4. Health conditions in Norway. Oslo: folkehelserapporten 2014:4. Helsetilstanden i norge; 2014

6. Association AP: Diagnostic and statistical manual of mental disorders (dsm$\left.5^{\circledR}\right)$ : American psychiatric pub; 2013

7. Hansen FA. Children living with parental substance abuse [barn som lever med foreldres rusmisbruk]. Oslo: Ad Notam Gyldendal; 1994.

8. Dawson DA, Grant BF, Chou SP, Stinson FS. The impact of partner alcohol problems on women's physical and mental health. J Stud Alcohol Drugs. 2007;68(1):66-75.

9. Hope A. Alcohol's harm to others in Ireland. Dublin: Health Service Executive; 2014

10. Laslett A-M, Room R, Ferris J, Wilkinson C, Livingston M, Mugavin J. Surveying the range and magnitude of alcohol's harm to others in Australia. Addiction. 2011;106(9):1603-11.

11. Birkeland B, Weimand B. Adult relatives to persons with substance abuse problems - a qualitative study on living conditions [voksne pårørende til personer med rusmiddelproblemer - en kvalitativ levekårsstudie]. Oslo: Helsedirektoratet; 2015.

12. Haugland BSM. Recurrent disruptions of rituals and routines in families with paternal alcohol abuse. Fam Relat. 2005;54(2):225-41.

13. Benishek LA, Kirby KC, Dugosh KL. Prevalence and frequency of problems of concerned family members with a substance-using loved one. Am J Drug Alcohol Abuse. 2011;37(2):82-8.

14. Orford J, Velleman R, Copello A, Templeton L, Ibanga A. The experiences of affected family members: a summary of two decades of qualitative research. Drugs Educ Prev Policy. 2010;17(sup1):44-62.

15. Birkeland B, Weimand BM, Ruud T, Høie MM, Vederhus J-K. Perceived quality of life in partners of patients undergoing treatment in somatic health, mental health, or substance use disorder units: a cross-sectional study. Health Qual Life Outcomes. 2017;15(1):172.

16. Barcaccia B, Esposito G, Matarese M, Bertolaso M, Elvira M, De Marinis MG. Defining quality of life: a wild-goose chase? Eur J Psychol. 2013;9(1): 185-203. 
17. Benito-León J, Rivera-Navarro J, Guerrero AL, Delas Heras V, Balseiro J, Rodríguez $\mathrm{E}$, et al. The caregol-ms was a useful instrument to measure caregiver quality of life in multiple sclerosis. J Clin Epidemiol. 2011; 64(6):675-86.

18. WHOQOL Group. Development of the world health organization whoqolbref quality of life assessment. Psychol Med. 1998;28(3):551-8.

19. Ventegodt S, Merrick J, Andersen NJ. Measurement of quality of life ii : from the philosophy of life to science. Sci World J. 2003;3:962-71.

20. Moons P, Budts W, De Geest S. Critique on the conceptualisation of quality of life: a review and evaluation of different conceptual approaches. Int J Nurs Stud. 2006:43(7):891-901.

21. Gill TM, Feinstein AR. A critical appraisal of the quality of quality-of-life measurements. JAMA. 1994;272(8):619-26.

22. Ware JE Jr, Sherbourne CD. The Mos 36-item short-form health survey (sf-36): I. conceptual framework and item selection. Med Care. 1992; 30:473-83.

23. Kuspinar A, Mayo NE. Do generic utility measures capture what is important to the quality of life of people with multiple sclerosis? Health Qual Life Outcomes. 2013;11(1):71.

24. Veenhoven R. The four qualities of life ordering concepts and measures of the good life. In: Delle Fave A, editor. The exploration of happiness. Dordrecht: Springer; 2013. p. 195-226.

25. McGillicuddy NB, Rychtarik RG, Papandonatos GD. Skill training versus 12step facilitation for parents of substance-abusing teens. J Subst Abus Treat. 2015;50:11-7.

26. Levac D, Colquhoun H, O'Brien KK. Scoping studies: advancing the methodology. Implement Sci. 2010;5(1):69.

27. Dogba MJ, Rauch F, Wong T, Ruck J, Glorieux FH, Bedos C. From pediatric to adult care: strategic evaluation of a transition program for patients with osteogenesis imperfecta. BMC Health Serv Res. 2014;14(1):489.

28. Arksey H, O'Malley L. Scoping studies: towards a methodological framework. Int J Soc Res Methodol. 2005:8(1):19-32.

29. Cicek E, Demirel B, Ozturk HI, Kayhan F, Cicek IE, Eren I. Burden of care and quality of life in relatives of opioid dependent male subjects. Psychiatr Danub. 2015;27(3):273-7.

30. Hussaarts P, Roozen HG, Meyers RJ, Van De Wetering BJ, BS MC. Problem areas reported by substance abusing individuals and their concerned significant others. Am J Addict. 2012;21(1):38-46.

31. Peters MD, Godfrey CM, Khalil H, Mclnerney P, Parker D, Soares CB. Guidance for conducting systematic scoping reviews. Int J Evid Based Healthc. 2015;13(3):141-6.

32. Elo S, Kyngäs $\mathrm{H}$. The qualitative content analysis process. J Adv Nurs. 2008; 62(1):107-15.

33. Jiang $H$, Callinan $\mathrm{S}$, Laslett AM, Room R. Correlates of caring for the drinkers and others among those harmed by another's drinking. Drug Alcohol Rev. 2015;34(2):162-9.

34. Stenton J, Best D, Roberts B. Social support, group involvement, and wellbeing among the family and friends of problem drinkers. J Groups Addict Recover. 2014;9(3):199-221.

35. Barber JG, Gilbertson R. Coping with a partner who drinks too much: does anything work? Subst Use Misuse. 1997:32(4):485-94.

36. Brown TG, Kokin M, Seraganian P, Shields $N$. The role of spouses of substance abusers in treatment: gender differences. J Psychoactive Drugs. 1995;27(3):223-30.

37. Casswell S, You RQ, Huckle T. Alcohol's harm to others: reduced wellbeing and health status for those with heavy drinkers in their lives. Addiction. 2011;106(6):1087-94.

38. Nogueira JM, Rodriguez-Miguez E. Using the sf-6d to measure the impact of alcohol dependence on health-related quality of life. Eur J Health Econ. 2015;16(4):347-56.

39. Brazier JE, Roberts J. The estimation of a preference-based measure of health from the sf-12. Med Care. 2004:42(9):851-9.

40. Brazier J, Roberts J, Deverill M. The estimation of a preference-based measure of health from the sf-36. J Health Econ. 2002:21(2):271-92.

41. Ware JE Jr. Sf-36 health survey update. Spine. 2000;25(24):3130-9.

42. Pyne JM, Tripathi S, French M, McCollister K, Rapp RC, Booth BM. Longitudinal association of preference-weighted health-related quality of life measures and substance use disorder outcomes. Addiction. 2011; 106(3):507-15

43. Eurogol: What is eq-5d? [http://www.eurogol.org/ Archived by Web-Cite ${ }^{\oplus}$ at http://www.webcitation.org/5rOuVGs4t.]
44. The International Wellbeing Group. Personal wellbeing index-adult, 4th edn. Melbourne: Australian Centre on Quality of Life, Deakin University;2006.

45. Cummins RA, Eckersley R, Pallant J, Van Vugt J, Misajon R. Developing a national index of subjective wellbeing: the australian unity wellbeing index. Soc Indic Res. 2003;64(2):159-90.

46. Evans DR, Cope WE. Quality of life questionnaire: multi-health systems; 1989

47. Eser S, Saatli G, Eser E, Baydur H, Fidaner C. The reliability and validity of the turkish version of the world health organization quality of life instrumentolder adults module (whogol-old). Turk Psikiyatri Dergisi. 2010;21(1):1.

48. Wolcott I, Glezer H: Marriage counselling in Australia: an evaluation: ERIC Melbourne: Australian Institute of Family Studies;1989.

49. Arcidiacono C, Velleman R, Procentese F, Albanesi C, Sommantico M. Impact and coping in italian families of drug and alcohol users. Qual Res Psychol. 2009;6(4):260-80.

50. Velleman R, Templeton L, Uk Alcohol D, The family research G. Alcohol, drugs and the family: results from a long-running research programme within the UK. Eur Addict Res. 2003;9(3):103-12.

51. Falkov A. The family model handbook: an integrated approach to supporting mentally ill parents and their children. Hove: Pavilion; 2012.
Ready to submit your research? Choose BMC and benefit from:

- fast, convenient online submission

- thorough peer review by experienced researchers in your field

- rapid publication on acceptance

- support for research data, including large and complex data types

- gold Open Access which fosters wider collaboration and increased citations

- maximum visibility for your research: over $100 \mathrm{M}$ website views per year

At $\mathrm{BMC}$, research is always in progress.

Learn more biomedcentral.com/submissions 